\title{
Hydrologic Conditions in Georgia, 2010
}

The United States Geological Survey (USGS) Georgia Water Science Center (GaWSC) maintains a long-term hydrologic monitoring network of more than 320 real-time streamgages, including 10 real-time lake-level monitoring stations and 63 real-time water-quality monitors. Additionally, the GaWSC operates more than 180 groundwater wells, 41 of which are real-time. One of the many benefits from this monitoring network is that the data analysis provides an overview of the hydrologic conditions of rivers, creeks, reservoirs, and aquifers in Georgia.

Streamflow data are verified throughout the year by USGS hydrographers, and this information is available to water-resource managers, recreationalists, and Federal, State, and local agencies. Hydrologic conditions are determined by comparing the results of statistical analyses of the data collected during the current water year ${ }^{1}$ (WY) to historical data collected over the long term. Changing hydrologic conditions emphasizes the need for accurate, timely data to help State and local officials make informed decisions regarding the management and conservation of Georgia's water resources for agricultural, recreational, and water-supply needs and for use in protecting life and property.

\section{Streamflow and Groundwater Data}

Daily, monthly, and yearly streamflow and groundwater statistics from the 2010 USGS annual data report (ADR; U.S. Geological Survey, 2011a) were used to develop this summary. Data for WYs 1999-2010 can be accessed online at http://ga.water.usgs.gov/publications/ pubswdr.html. At this website, a digital map allows the user to search for current and historical data and graphics collected as part of the USGS monitoring network.

${ }^{1}$ Water year is the period October 1 through September 30 and is designated by the year in which it ends. For example, the 2010 water year began on October 1, 2009, and ended on September 30, 2010.

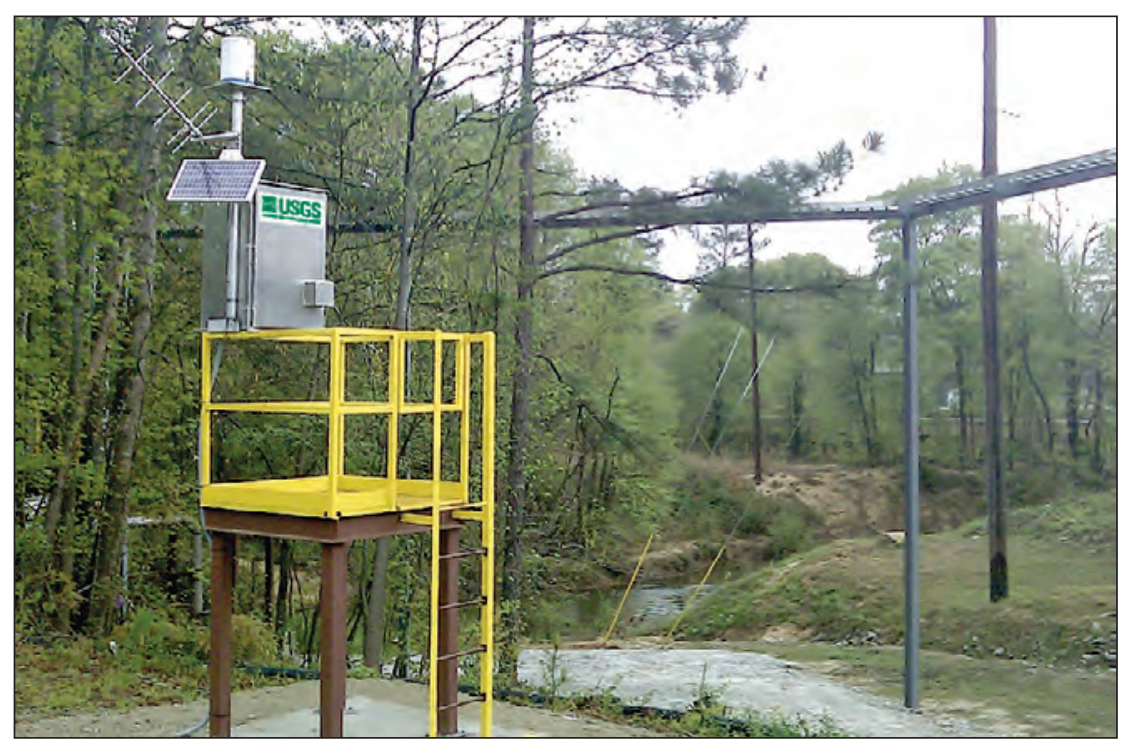

Streamflow station 02336910 Sweetwater Creek at Austell, Georgia (photograph by Andrew E. Knaak, April 8, 2010).

Quarterly Hydrologic Conditions in Georgia for 2010 WY, Based on Drainage Basin Runoff

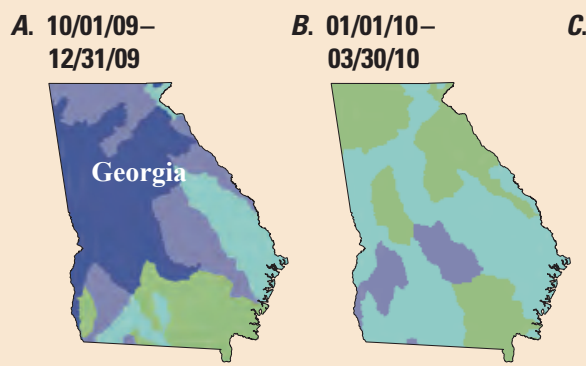

These maps represent 2010 WY hydrologic conditions compared to available historical data. The colors represent runoff (flow per unit area) as a percentile range of long-term averages. Runoff was calculated for each basin and assumed to be uniform over the entire basin area. Only streamflow stations with a complete daily-flow dataset for the 2010 WY were used (U.S. Geological Survey, 2010b). Historic flooding near the end of the 2009 WY coupled with high rainfall throughout the first quarter of the 2010 WY resulted in some of the highest runoff percentiles observed on record (map $A$ ). The second and third quarters of the 2010 WY transitioned from above normal

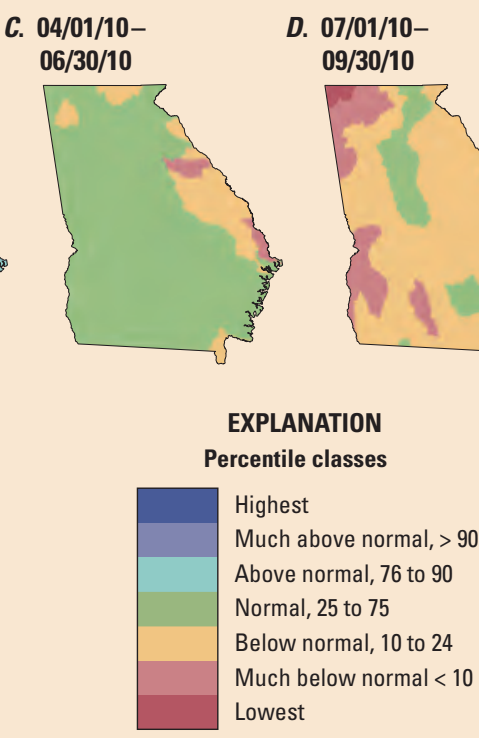

to normal (maps $B, C$ ). Extreme summer temperatures combined with little precipitation resulted in decreased runoff, and by the fourth quarter, runoff throughout most of the State was below normal (map D). The northwestern corner of the State had some of the lowest runoff conditions on record. 


\section{Chattooga River at Summerville 02398000}

The Chattooga River flows in the northwestern corner of Georgia and into Alabama where it flows into Weiss Lake (U.S. Geological Survey, 1975). The 7-day average streamflow was "much above normal," in October and November and historical maximum daily values were recorded in response to persistent precipitation throughout Fall of 2009. The 7-day average streamflow was "normal" beginning in January 2010 before gradually declining to "below normal" towards the end of the

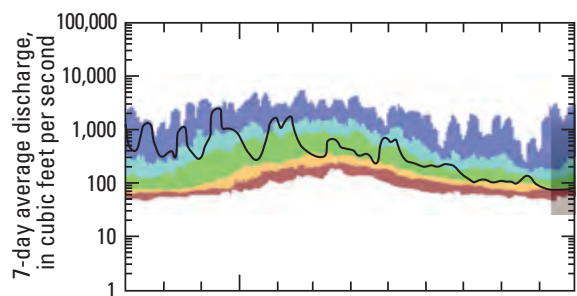
water year.

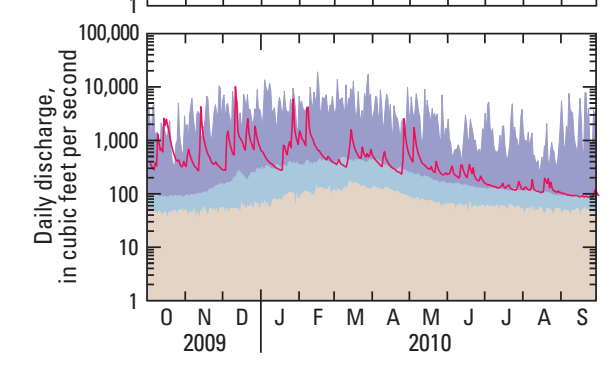

\section{Daily Discharge and 7-Day Average Streamflow Conditions, 2010 Water Year}

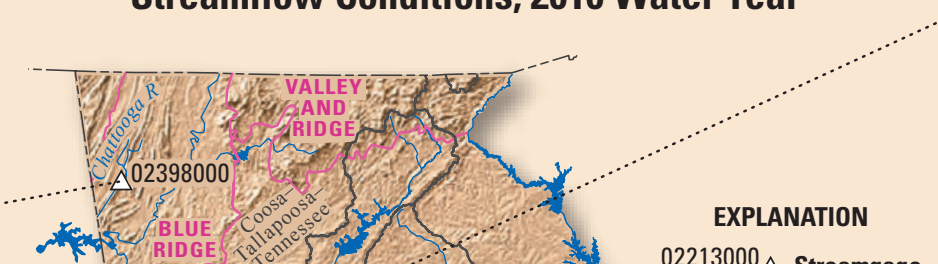

EXPANATION

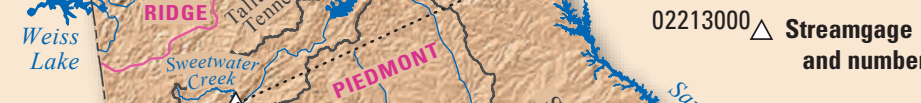

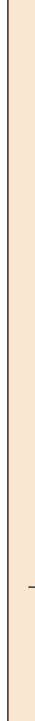

\section{Ocmulgee River at Macon 02213000}

The Ocmulgee River flows out of Jackson Lake and joins the Oconee River to form the Altamaha River (U.S. Geological Survey, 1975). In 2010, new record daily maximum streamflows were observed for the months of October, November, and December. The 7-day average streamflows were "normal" to "much above normal" throughout much of the year with the exception of a short period in April when 7-day average streamflow was "below normal."
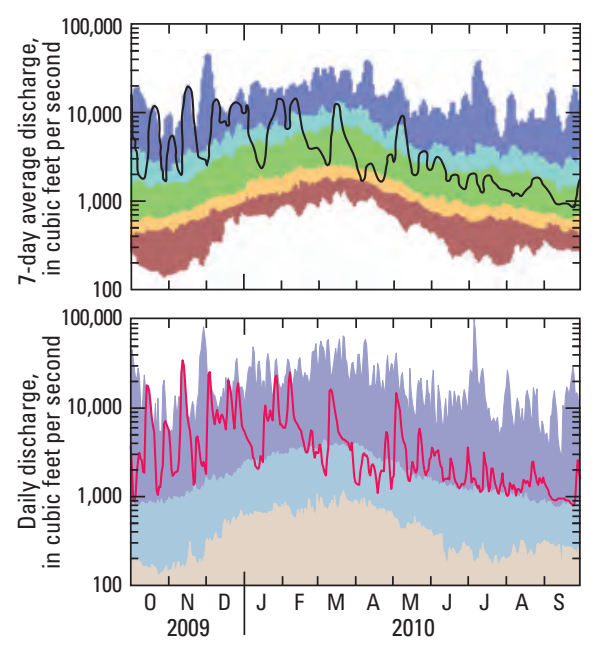

\section{7-Day Average Discharge}

Hydrographs show 2010 daily-mean streamflow, in cubic feet per second, as compared to historical minimum and median streamflow for the entire period of record (U.S. Geological Survey, 2011a).
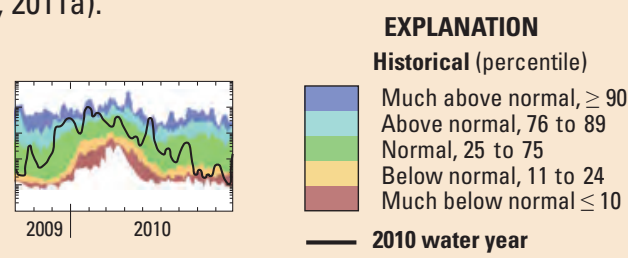

\section{Daily Discharge}

Hydrographs show the 7-day average for 2010 as compared to historical 7-day averages. Data are categorized in percentile ranges from "much above normal" (greater than the 90th percentile) to "much below normal" (less than the 10th percentile; U.S. Geological Survey, 2011b).
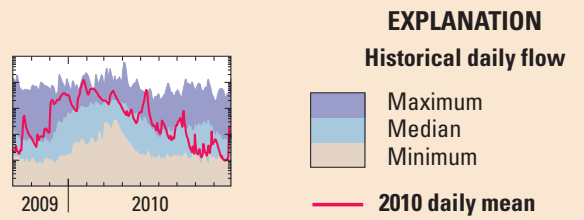


\section{Sweetwater Creek near Austell 02337000}

Sweetwater Creek is a major tributary of the Chattahoochee River (U.S. Geological Survey, 1975). The 7-day average streamflow in October and November was "much above normal," and historic maximum daily values were recorded as a result of persistent precipitation that followed the September 2009 flooding event (U.S. Geological Survey, 2010a). The 7-day average streamflow remained "normal" for most of the year before declined. By August and September, streamflow declined to "much below normal" due to extreme summer temperatures and little precipitation.
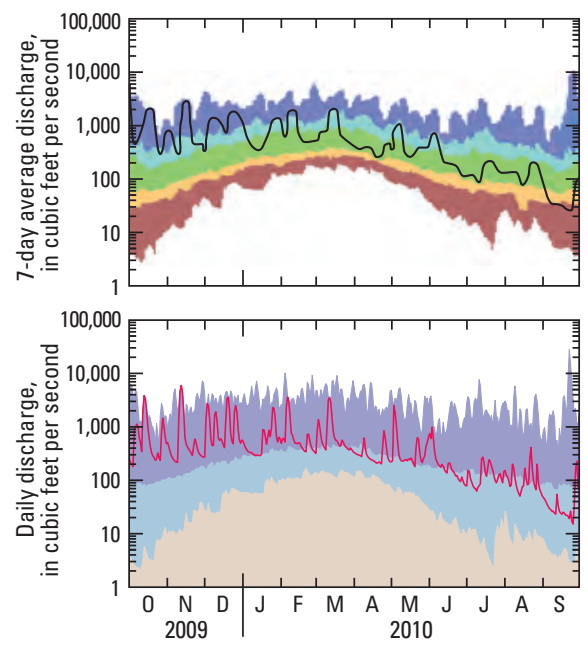
it gradually

\section{Climate Response Network}

The USGS maintains a network of groundwater wells to monitor the effects of droughts and other climate variability on groundwater levels. These wells are part of the Climate Response Network, which is designed to measure the effects of climate on groundwater levels in unconfined aquifers or near-surface confined aquifers where pumping or other human influences on groundwater levels are minimal (U.S. Geological Survey, 2007, 2010b). The national network consists of about 130 wells, of which 15 are located in Georgia. Information obtained for the $2010 \mathrm{WY}$ from 4 of these wells is summarized in this section. These wells are monitored as part of the USGS Groundwater Resources and Cooperative Water Programs. Current conditions of groundwater wells in the Climate Response Network can be accessed online at http://groundwaterwatch.usgs.gov/.

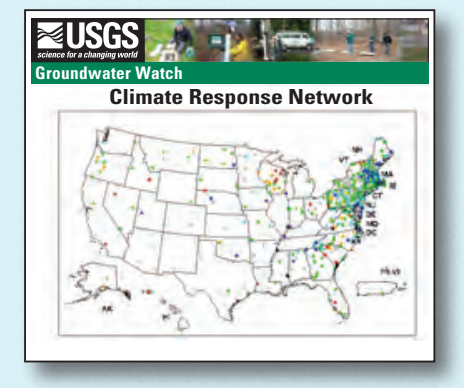

Well $07 \mathrm{HOO2}$ is in Miller County in southwestern Georgia and is completed in the Upper Floridan aquifer, which is a and declines

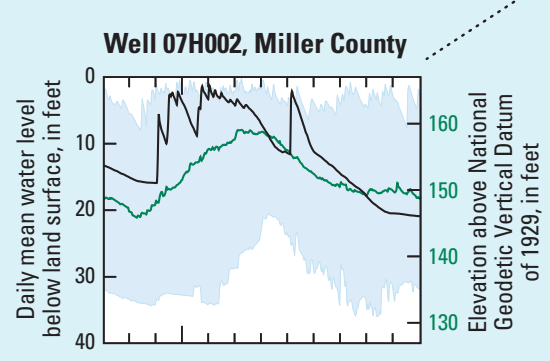

The Withlacoochee River flows in the Ochlockonee River basin in the southern coastal plain of Georgia (U.S. Geological Survey, 1975). Historic flooding events in the 2009 WY brought much needed drought relief to southern Georgia, and this had a positive effect on discharge in Withlacoochee River that persisted into the 2010 WY. For most of the 2010 WY, 7-day average streamflow conditions were "normal." Daily discharges during October through December were in the maximum historical daily discharge
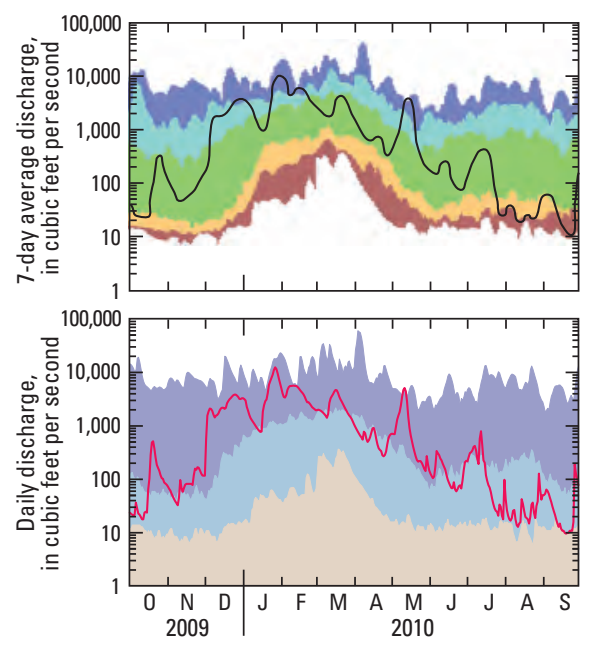

range. semiconfined aquifer in this area (Torak and others, 2010). The water level in this well generally rises rapidly during wet periods slowly during dry periods. The water level

in well $07 \mathrm{H0O2}$
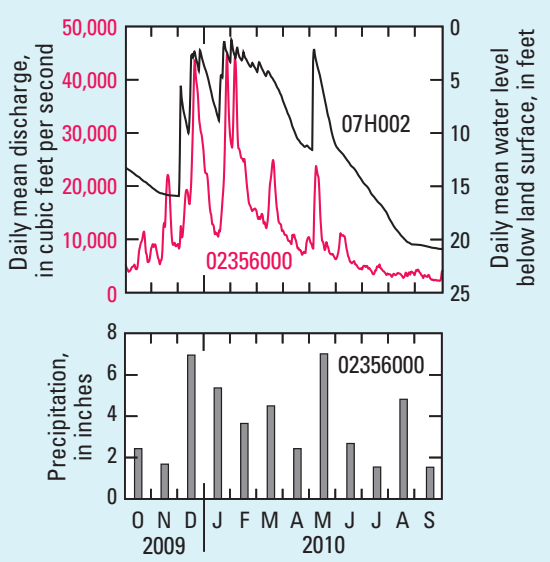

responds to seasonal change similarly to streamflow at the nearby streamgage on the Flint River at Bainbridge (02356000), which indicates atmospheric, surface-water, and groundwater interactions. In the 2010 WY, water levels in well 07H002 were above the historical median for much of the year except during April and August through September when water levels fell below historical daily medians in response to increased air temperature and low monthly precipitation. 


\section{Georgia's Climate Response Network}

The hydrographs presented are for selected wells in Georgia with at least five years of continuous data.

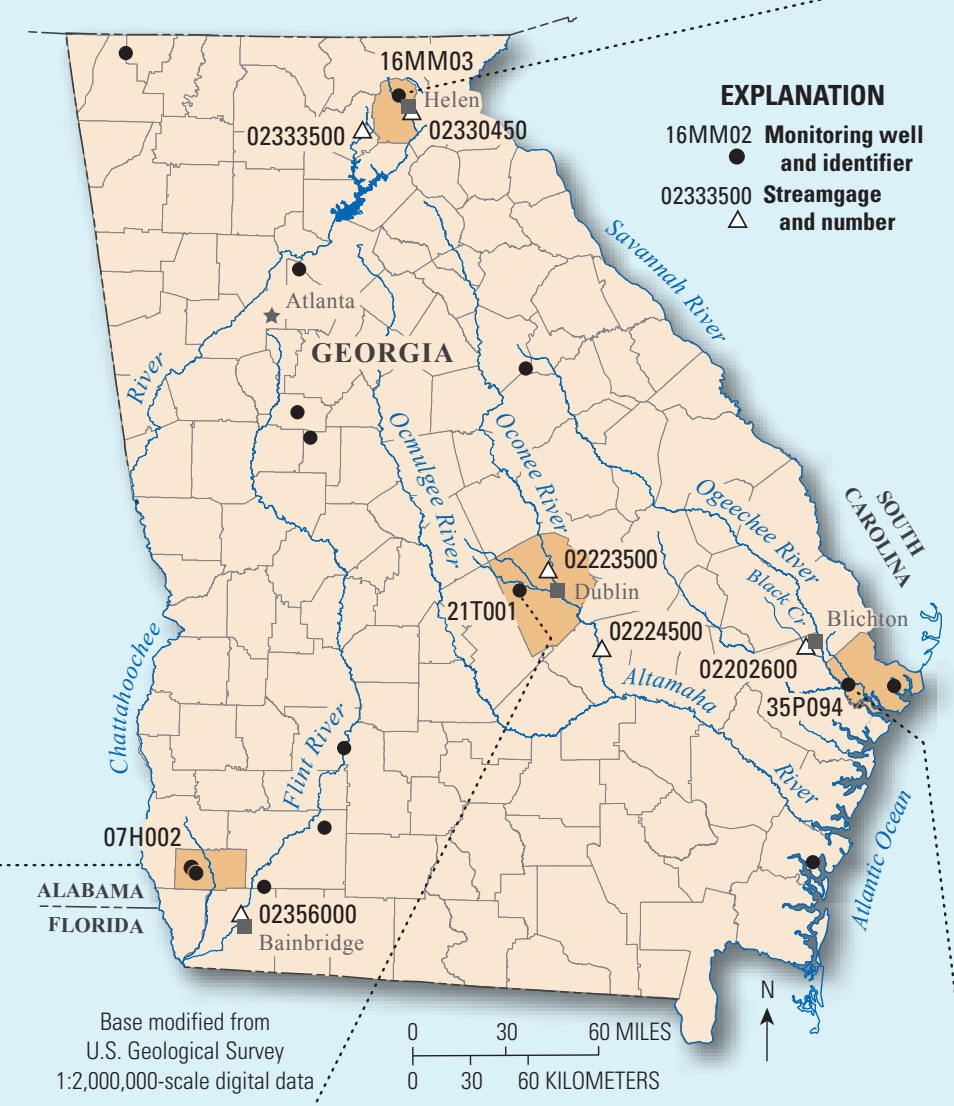

Well 21T001 is in Laurens County in east-central Georgia and is completed in a semiconfined part of the Upper Floridan aquifer. Water levels in semiconfined parts of the aquifer fluctuate seasonally in response to variations in precipitation, evapotranspiration, and natural drainage or discharge (Peck and others, 2011). The water level in well $21 \mathrm{T001}$ responds to seasonal change similarly to streamflow at the nearby streamgage

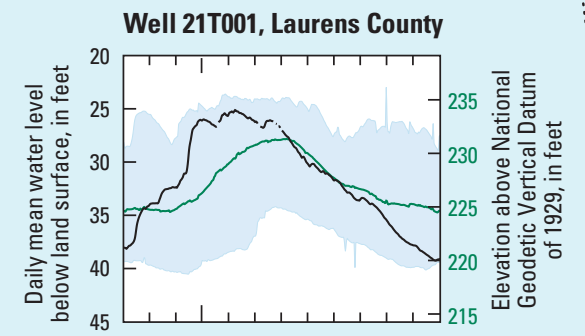

on the Oconee River near Dublin (02223500), which indicates atmospheric, surface-water, and groundwater interactions. At the beginning of $2010 \mathrm{WY}$, water levels in well 21 T001 were well above the historical daily median. During June 2010 water levels dropped below the daily median and by the end of the water year were near an all-time historic low in response to low monthly precipitation in the area after March 2010.
Well 16MM03 is in White County in northeastern Georgia and is completed in the crystalline-rock aquifer. Water is stored in the regolith and fractures, and the water level is affected by precipitation and evapotranspiration (Cressler and others, 1983). Precipitation can cause a rapid water-level rise in wells tapping aquifers overlain by thin regolith (Peck and others, 2011). The water level in well 16MM03 responds to seasonal change similarly to streamflow at the nearby streamgage on the Chattahoochee River at Helen (02330450), which

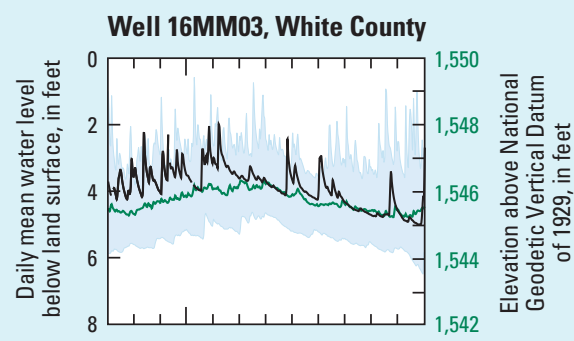
indicates atmospheric, surface-water, and groundwater interactions. The water level in well 16MM03 remained above the historical daily median for the first several months of the 2010 WY. The highest water level below land surface for the 2010 WY occurred in December 2009 when the area received nearly 10 inches of precipitation during the month.

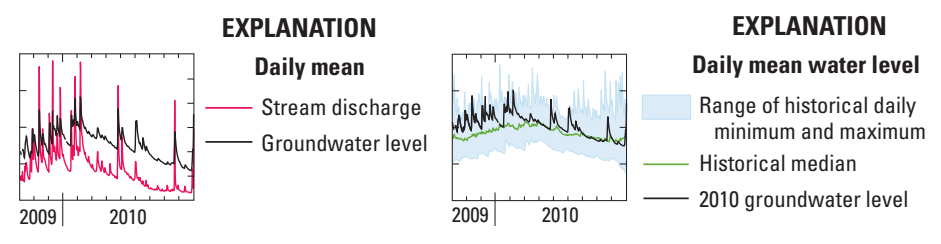

Well 35P094 is in Chatham County in southeastern Georgia and is completed in the surficial aquifer. Water levels in this well generally rise rapidly during wet periods and decline slowly during dry periods. The water level in well 35P094 responds to seasonal change similarly to streamflow at the nearby streamgage on Black Creek near Blitchton (02202600), which indicates atmospheric, surfacewater, and groundwater interactions. The water level in well 35P094 remained above the historical daily median during 0 ctober through early June then fell below the historical median
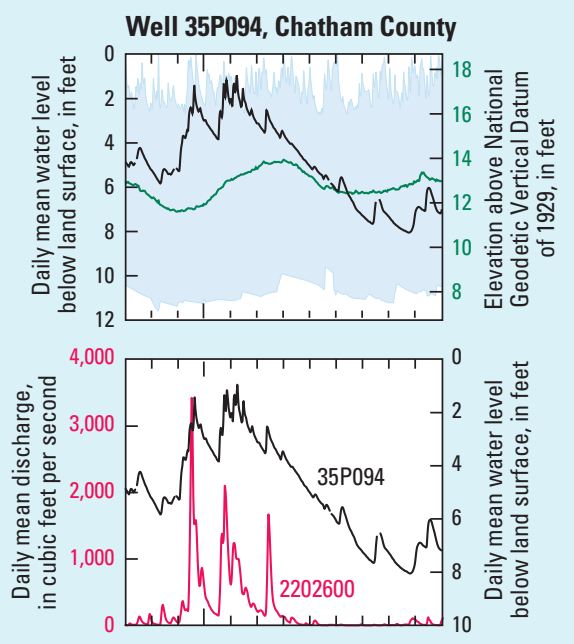
for the remainder of the 2010 WY. The highest water level below land surface for the year occurred in February 2010. 


\section{Lakes and Reservoirs}

Major lakes and reservoirs throughout Georgia are managed primarily by the U.S. Army Corps of Engineers and Georgia Power Company to provide water for public and industrial use, flood protection, power generation, wildlife management, and recreation. Managing lakes and reservoirs requires computer models that rely on USGS data to predict changes in climate and water demands. During the first half of the 2010 WY, water levels in Hartwell Lake and Lake Sidney Lanier rose above the top of conservation-pool levels following two separate historical flooding events in the 2009 WY.

Lake Sidney Lanier on the Chattahoochee River is the primary drinkingwater source for the Atlanta metropolitan area. Lake Lanier is the most upstream reservoir in a series of reservoirs that include West Point Lake, Walter F. George Lake, and Lake Seminole. Lake Lanier had slightly more inflow than outflow during the $2010 \mathrm{WY}$, and the lake elevation remained, fluctuating above and below the top of conservation-pool level (1,071 feet,). The elevation of West Point Lake was regulated to maintain water level near the top of conservation pools. The volume of Lake Lanier is nearly 14 times greater than the volume of West Point Lake, West Point Lake remains near full-pool elevation even in times of drought. West Point Dam provides flood protection and hydroelectric power to Troup County, and its construction was authorized by the Flood Control Act of 1962 (U.S. Army Corps of Engineers, 2009c).

Hartwell Lake is on the border between Georgia and South Carolina on the Savannah and Tugaloo Rivers. Hartwell Lake is the most upstream major reservoir on the Savannah River. Water is released to the downstream reservoirs, Richard B. Russell and J. Strom Thurmond. These three lakes on the Savannah River are managed by the U.S. Army Corps of Engineers for water supply, power generation, and water-quality needs of the Savannah River from below Thurmond Dam all the way to Savannah, Georgia, and the Atlantic Ocean (U.S. Army Corps of Engineers, 2009a). Hartwell Lake reached an all-time historical low elevation during the 2009 WY, but lake elevations increased rapidly in response to the historical September 2009 flooding event, and water levels were above the top of conservation-pool levels 9 out of 12 months during the $2010 \mathrm{WY}$.
Allatoona Lake is on the Etowah River and is managed by the U.S. Army Corps of Engineers. During the 2010 WY, Allatoona Lake remained above the top of the conservation-pool level from October 2009 to July 2010. In August and September 2010, water levels dropped below the top of the conservation-pool level as a result of more than twice the amount of outflow than inflow.
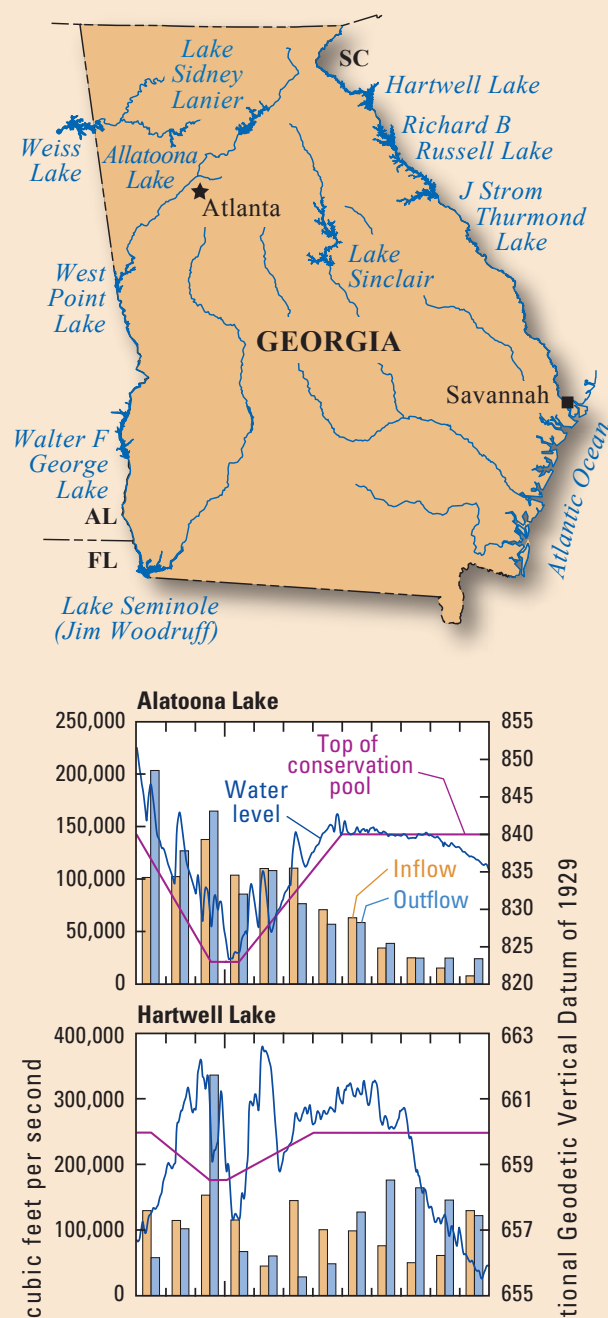

$\subseteq 180,000$ Lake Sidney Lanier $1,074 \underset{\substack{\pi \\ Z}}{\stackrel{0}{\frac{0}{\pi}}}$
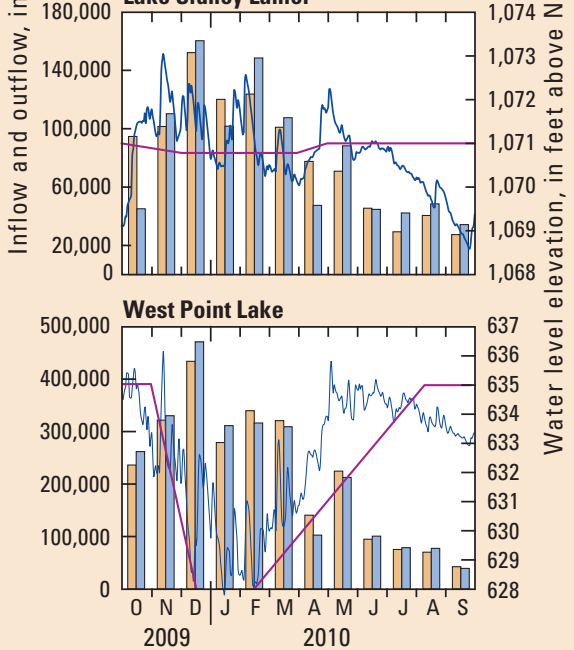

(Data from U.S. Army Corps of Engineers, 2009a)

\section{USGS Water-Quality Network in Georgia}

The USGS in cooperation with the Georgia Department of Natural Resources Environmental Protection Division (GaEPD) collected discrete water-quality samples at 49 long-term monitoring stations and 3 continuous water-quality monitoring stations. Data have been collected to determine trends at some of the 49 long-term monitoring stations since 1968. Data from the network assist the GaEPD in meeting responsibilities under the Clean Water Act, including (1) identifying the beneficial uses of surface waters within the State, (2) establishing water-quality standards to maintain the full beneficial uses of those waters, and (3) identifying water bodies where stream standards are not met and beneficial uses are impaired (Grams, 2011). Water-quality data for Georgia streams are available on a publicly accessible website at: http://waterdata.usgs.gov/ga/nwis/qw/.

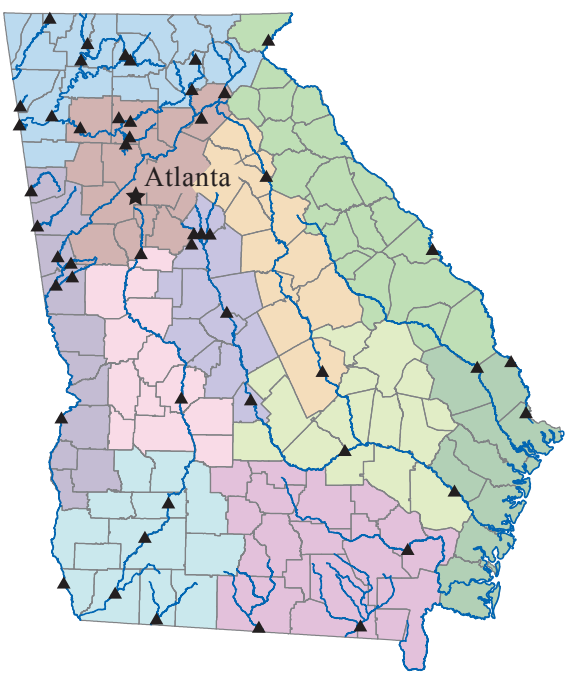

EXPLANATION

Georgia water planning regions

Altamaha

Coastal Georgia

Coosa-North Georgia

Lower Flint-0chlockonee

Metro North Georgia

Water Planning District

Middle Chattahoochee

Middle $0 \mathrm{cmulgee}$

Savannah-Upper Ogeechee

Suwannee-Satilla

Upper Flint

Upper Oconee

- 2010 EPD discrete QW station 


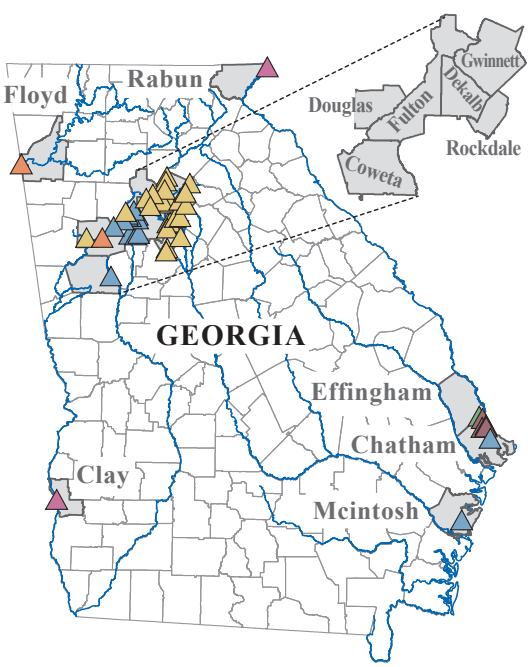

EXPLANATION

Water quality network 2010 water year
$\triangle W T$
$\triangle W T, S C, D O, p H, N T U$
$\triangle W T, S C$
$\triangle W T, S C, N T U$
$\triangle \mathrm{WT}, \mathrm{SC}, \mathrm{DO}, \mathrm{pH}$
$\triangle W T$, SC, Salinity

WT, water temperature; SC, specific conductance; DO, Dissolved oxygen; $\mathrm{pH} ; \mathrm{NTU}$, nephelometric turbidity units; Salinity

Water-quantity and water-quality information are equally important for insuring adequate water availability for human consumption, industrial uses, and aquatic ecosystems. Streamflow conditions are a primary driver of nonpoint-source-related water quality and the most important component affecting water quality in streams (Hirsch and others, 2006). Real-time streamflow and water-quality monitors can be used to improve estimated real-time concentrations and loads of many constituents including sediment, nutrients, and trace elements.

Current water-quality conditions at real-time water-quality monitors maintained in the GaWSC network (see map on left) can be accessed online at http://waterwatch.usgs.gov/wqwatch/ (U.S. Geological Survey, 2010c). Current real-time data, which are useful for understanding aquatic ecosystem health, include water temperature, dissolved oxygen, and $\mathrm{pH}$. Specific conductance and turbidity help aid in identifying timing of pollutants. Several real-time water-quality monitors are located in urban watersheds near the Atlanta metropolitan area, including Gwinnett County (17), Fulton County (10), Dekalb County (4), and Douglas County (1).

The hydrographs (see graph on right) show the relation between water quantity (discharge) and water quality over the duration of a storm at USGS streamgage 02208150 on the Alcovy River near Grayson, Georgia. During the storm on October 9, 2009, turbidity initially increased prior to the peak of stormwater runoff from sediment washing from impervious surfaces and then decreased with increasing discharge. Specific conductance and water temperature decreased with increasing discharge because of the lower amount of dissolved constituents in rainfall and lower temperatures. As streamflow returned to baseflow following the storm, conductance and temperature returned to pre-storm conditions. Storm runoff response such as this is site specific.
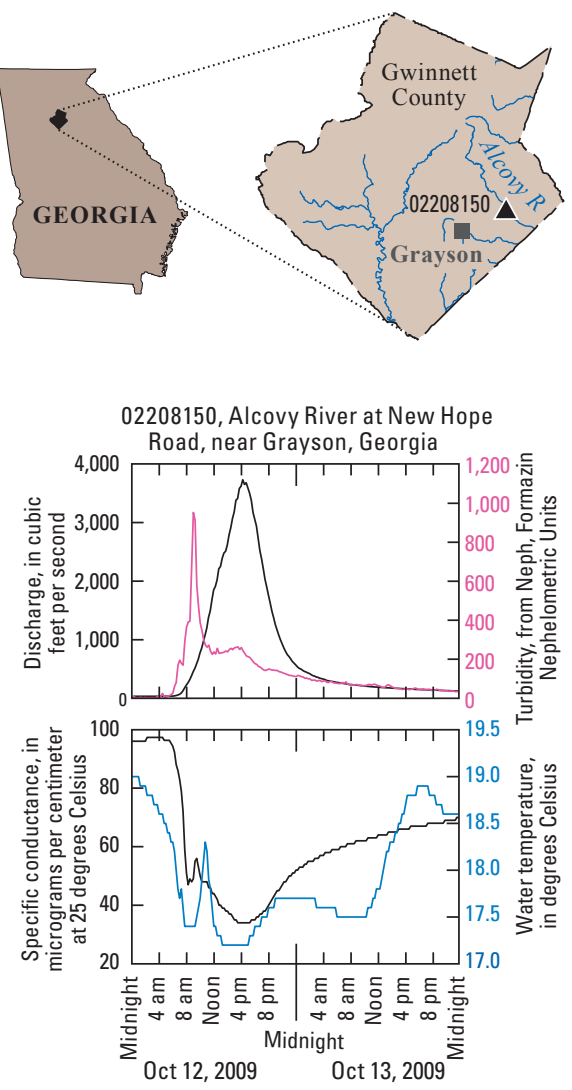

\section{References}

Cressler, C.W., Thurmond, C.J., and Hester, W.G., 1983, Ground water in the greater Atlanta region, Georgia: Georgia Geological Survey Information Circular 63, $144 \mathrm{p}$.

Georgia Automated Environmental Monitoring Network, 2010, Record high air temperatures, accessed on November 1, 2010 at $h t t p: / / w w w$. georgiaweather.net/.

Grams, S.C., 2011, Benefits of long-term waterquality monitoring in Georgia [abs.]: University of Georgia, Athens, Proceedings of the 2011 Georgia Water Resources Conference, April 11-13, 2011, 1 p. Proceedings of the Georgia Water Resources Conference, 6.1 Watershed Data, April 2011.

Hirsch, R.M., Hamilton, P.A., and Miller, T.L., 2006, U.S. Geological Survey perspective on waterquality monitoring and assessment: Journal of Environmental Monitoring, v. 8, p. 512-518.

Peck, M.F., Leeth, D.C., and Painter, J.A., 2011, Ground-water conditions and studies in Georgia, 2008-2009: U.S. Geological Survey Scientific Investigations Report 2011-5048, 83 p.; at http://pubs.usgs.gov/sir/2011/5048/.

National Climatic Data Center, 2009, National Environmental Satellite, Data, and Information Service: National Oceanic and Atmospheric Administration, accessed November 1, 2010, at $h t t p: / / w w w . n c d c . n o a a . g o v /$.
Torak, L.J., Painter, J.A., and Peck, M.F., 2010, Geohydrology of the Aucilla-SuwanneeOchlockonee River Basin, south-central Georgia and adjacent parts of Florida: U.S. Geological Survey Scientific Investigations Report 2010-5072, 78 p.

U.S. Army Corps of Engineers, 2009a, Hartwell Dam \& Lake: U.S. Army Corps of Engineers, Savannah District, accessed May 1, 2010, at http://www.sas.usace.army.mil/lakes/hartwell/ intro.htm\#funfacts.

U.S. Army Corps of Engineers, 2009b, Lake elevations, inflows and outflows, accessed May 1, 2010, at http://www.sas.usace.army.mil/.

U.S. Army Corps of Engineers, 2009c, West Point Lake: U.S. Army Corps of Engineers, Mobile District, accessed May 1, 2010,

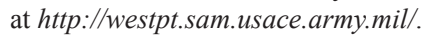

U.S. Geological Survey, 1975, Hydrologic unit map 1974, State of Georgia: U.S. Geological Survey, scale 1:500,000, 1 sheet.

U.S. Geological Survey, 2007, U.S. Geological Survey Ground-Water Climate Response Network: U.S. Geological Survey Fact Sheet 2007-3003, 4 p., accessed July 1, 2009, at http://pubs.usgs.gov/fs/2007/3003/.

U.S. Geological Survey, 2010a, Historic Flooding in Northern Georgia, September 16-22, 2009: U.S. Geological Survey Fact Sheet 2010-3061,
2 p., accessed August 10, 2010, at http://pubs. usgs.gov/fs/2010/3061/.

U.S. Geological Survey, 2010b, U.S. Geological Survey Groundwater Watch, Climate Response Network, accessed August 1, 2011, at http://groundwaterwatch.usgs.gov/.

U.S. Geological Survey, 2010c, Water Quality Watch - Continuous real-time water quality in the United States, accessed August 1, 2011, at http://waterwatch.usgs.gov/wqwatch/.

U.S. Geological Survey, 2011a, U.S. Geological Survey annual data report for Georgia, water year 2010, accessed August 1, 2011, at http:// ga.water.usgs.gov/publications/pubswdr.html.

U.S. Geological Survey, 2011b, WaterWatchCurrent water resources conditions, accessed May 1, 2011, at http://waterwatch.usgs.gov/.

By Andrew E. Knaak, Paul D. Ankcorn, and Michael F. Peck

For more information contact: Director, USGS Georgia Water Science Center 3039 Amwiler Road, Suite 130 Atlanta, Georgia 30360 770-903-9100 http://ga.water.usgs.gov/ 